Совгира Тетяна Ігорівна, аспірантка, Київський національний університет культури імистецтв

\title{
ТЕХНОЛОГІЯ ВИРОБНИЦТВА ТВОРІВ ТЕЛЕВІЗІЙНОЇ ЕСТРАДИ
}

У статті розглядається прочес продукування творів телевізійної естради. 3'ясовується зміст понять «сиенарій», «сиенарний план», «монтажний лист», «nартитура» тощо. На основі теоретичного дослідження особливостей подібності сценічної естради та телебачення виявлено закономірності взаємодії ичих мистецтвв.

Ключові слова: телевізійна естрада, шоу, режисер.

В статье рассматривается процесс продуцирования (создания) произведений телевизионной эстрады. Выясняется содержание понятий «сченарий», «сценарный план», «монтажный лист», партитура» и др. На основе теоретического исследования особенностей сходства сиенической эстрады и телевидения выявлены закономерности взаимодействия этих искусств.

Ключевые слова: телевизионная эстрада, шоу, режиссер.

In the articles found out the production process (creation) compositions of television variety and investigated maintenance of "script», "scenario plan», "assembly list», «score» and so on. Based on the theoretical study features similarities stage variety and television revealed patterns of interaction between this arts.

Keywords: televisional variety, show, director.

Естрадні програми на телебаченні з'явилися приблизно півстоліття тому, і з тих пір їхнє виробництво стрімко зростає, нині вони становлять значну частку розважальних телевізійних програм.

Тому цілком зрозумілий науковий інтерес до цього явища: його аналізували професор московського університету Е. Багіров («Нариси теорії телебачення») [1], професор ВДІК Н. Горюнова («Художньо-виразні засоби екрана») [5], А. Вартанов («Телевизионные зрелища») [3], С. Безклубенко («Телевизионное кино. Очерк теории») [2], В. Вільчек («Под знаком ТВ») [4]. У цих та інших публікаціях розглядаються різні аспекти функціонування творів сценічного естрадного мистецтва на телебаченні, але комплексне дослідження телевізійної естради як особливого продукту взаємодії телебачення та сценічної естради відсутнє. Цим зумовлений вибір теми дослідження: телеестради як продукту взаємодії телебачення та сценічної (театральної) естради.

Мета статті - розглянути основні етапи процесу виробництва творів телевізійної естради. 
Процес виробництва телевізійної естради є досить складним і пред’являє певні технологічні та творчі вимоги до роботи режисера на трьох основних етапах: перед зйомками, під час зйомок і після них, коли режисер здійснює монтаж проекту.

Перший етап - найтриваліший і найвідповідальніший. Від його початку залежить успіх усієї роботи. На цьому етапі важливим є дозрівання режисерського задуму та формулювання його «на папері». Тільки після того, як режисер-художник знайшов образне вирішення всіх епізодів, він може почати займатися питаннями технології втілення свого задуму. Може статися так, що не все придумане режисером одразу буде «піддаватися» технічній реалізації, але зрештою після певних зусиль знаходяться відповідні засоби для вирішення того чи іншого творчого завдання. Цей пошук стає можливим завдяки запису режисерського сценарію - основного літературного документа майбутнього дійства, який має створюватися з урахуванням можливостей технологічної, фізичної й одночасно творчої роботи всього колективу, зайнятого в постановці. Він вимагає побудови всіх епізодів у двох площинах: загальному студійному вирішенні та загальному екранному вирішенні постановки.

Технологія виробництва творів телевізійної естради передбачає можливість використання методу багатокамерної зйомки, що істотно економить час виробництва. Процес монтажу відбувається одночасно зі зйомкою, безпосередньо на майданчику. Усі камери, закадровий голос коментатора, а також результат монтажу, пишуться на жорсткий диск в реальному часі. Тому, після закінчення заходу, режисер має готовий варіант попереднього монтажу з усіх камер.

Враховуючи те, що естрадні видовища проходять у режимі «он-лайн», коли розвиток подій непередбачуваний, використання кількох камер є вкрай важливим, оскільки воно дозволяє не тільки не загубити важливі моменти, але і зафіксувати найбільш виразні кадри (і крупний, і середній, і загальний план однієї і тієї ж сцени).

3 огляду на це, у режисерському сценарії повинна бути передбачена можливість роботи декількох камер одночасно, тобто мають буди технологічно правильно вибудувані мізансцени, кадри, монтажні стики. У ньому повинна міститися достатня інформація для створення асистентського сценарію, сценарію звукорежисера, монтажних листків і світлової партитури. Це неодмінні технологічні вимоги, і вони повинні бути дотримані.

Тому методика створення літературної бази телевізійно-естрадного заходу досить складна та своєрідна. Але перше, з чого повинен починати режисер, це, виходячи із загального образного рішення, розбити матеріал на режисерські епізоди i, не обмежуючи себе технологічними вимогами, образно вирішити кожен епізод.

Потім, так само не обмежуючи себе технологією, шукати найкращі варіанти втілення образної думки епізоду. Побудова мізансцени повинна передувати розкадруванню. Побудові монтажного строю епізоду обов'язково повинне передувати розгорнення епізоду в часі і просторі.

У масштабних проектах задіяні два і більше режисерів, але головними є режисерпостановник і режисер за пультом (режисер ПТС). Вони мають для відтворення свого задуму два роди матеріалу: 
1. Первинний матеріал, що режисер складає за допомогою художника, актора, композитора. Можливість існування деяких художніх компонентів у вигляді самостійних творів (сценарій, музика до кінофільму чи телепостановки і т. д.) аж ніяк не знімає в них допоміжної функції при створенні екранного твору - вони його частина, що органічно входить в екранне ціле.

2. Вторинний, остаточний, матеріал - екранна площина, на якій за допомогою певних технічних засобів створюється динамічна художня модель явища дійсності. Саме на екранній площині остаточно завершується доробок.

Тут у свою чергу відбуваються два етапи: початковий, коли кожен кадр намічається як чорнетка, технічно обробляється (що, безумовно, впливає на його художні властивості), фіксується, і кінщевий, коли з усіх відзнятих кадрів створюється остаточно екранний твір.

Після створення режисерського сценарію режисери разом із операторами беруть участь у розстановці камер, працюють з освітленням. При цьому необхідна особливо ретельна установка освітлювальних приладів, що дає можливість вести різнопланову і багаторакурсну зйомку, і акуратна установка камер - так, щоб жодна не потрапляла у поле зору іншої і мала можливість пересування на хоча б незначні відстані.

Під час однієї зйомки телепроекту у підпорядкуванні режисера може бути одночасно до 35 камер. Кожен оператор знімає матеріал у чіткій послідовності за наказом режисера - план, ракурс, освітлення, кількість кадрів тощо.

До режисера видовища телевізійної естради висуваються високі вимоги. Він повинен об'єднувати і спрямовувати діяльність акторів-виконавців, ведучих, журналістів, музикантів, композиторів, звукорежисерів, художників, операторів і т. д, тобто всіх персон, задіяних в об'ємному виробничому процесі. Він може бути режисером монтажу телесюжету, програми або телефільму; пультовим режисером прямого та непрямого ефіру при багатокамерному методі зйомки; іноді йому доводиться бути журналістом, і ведучим інтерв'ю, репортажів.

Для того, щоб звалити собі на плечі такий вантаж, режисерові треба володіти як загальнопрофесійними знаннями у сфері естрадного та театрального мистецтв, кінодраматургії, кінооператорської майстерності, звукового вирішення фільму, теорії й історії музики, вітчизняного і зарубіжного кіно, літератури, образотворчого мистецтва, так і спеціальними навиками в частині режисури ігрового кіно-, теле- i відеофільму, теорії і практики монтажу, майстерності актора, культури і техніки мови, кінотехніки, кінотехнології і відеотехніки.

Фахівцю на телебаченні завжди стануть у нагоді знання основ фотокомпозиції, режисури неігрового фільму, теорії і практики монтажу, мультиплікації і комп'ютерної графіки, сучасного документального фільму, режисури анімаційного фільму, акторської майстерності, пантоміми, анімації, теорії і практики комп’ютерної графіки, кіно- і телезнімальної техніки, а також журналістики. Тому на практиці найчастіше трапляється так, що режисер володіє лише частиною з перерахованих навиків, як правило, з тієї сфери, де йому доводилося працювати найбільше.

Показовим є приклад виробництва проекту телевізійної естради «Україна має талант» («СТБ»), де видно, скільки доводиться робити режисерові на всіх етапах їі 
виробництва. Загальновідомо, що головними дійовими особами були самодіяльні артисти з різних регіонів країни, різного віку і соціального стану, талановиті в найрізноманітніших сферах життєдіяльності; на «велику сцену» доморослі таланти потрапляли після декількох відбірних етапів - спочатку це редактори, що працюють в регіонах, а після цього київська група: генеральний, лінійний продюсери і режисерпостановник. При відборі увага зверталася на те, щоб номер був не тільки цікавим за змістом, але і видовищним - такі умови диктує специфіка естради та телебачення. Спочатку талановитих учасників запрошували на репетиційний майданчик, де ставили номери, розробляли костюми, редагували або повністю змінювали музику, відібрану виконавцем, готували інсталяції, декорації і т. д. І нарешті, самі зйомки - відбіркові тури, фінали, півфінали і т. д.

Зйомкам кожного випуску відводився один день: сюди входять репетиції до обіду, коли оператор «проходив» усі номери зі світлом, і самі зйомки. На весь термін запису блоків режисер ставав головною особою в знімальному павільйоні.

У проекті було задіяно два режисери: режисер-постановник і режисер за пультом. Це пов'язано з великим обсягом роботи, а також з необхідністю присутності на зйомках двох фахівців одночасно. Режисер-постановник має відстежувати все, що відбувається за кулісами та на сцені, керує діями постановочної бригади та знімальної групи, даючи вказівки про готовність артистів, сцени, декорацій, про паузу для запису реклами тощо. Режисерові за пультом необхідні ці узгодження, щоб у свою чергу давати вказівки операторам: яку величину і ракурс узяти в той чи інший момент, і самому вчасно перемикати зображення з однієї камери на іншу. Перед його очима знаходиться безліч моніторів, на які надходить картинка з різних камер, i він вибирає найкраще на цей момент зображення, яке в режимі реального часу видається в ефір або записується на плівку.

У програмі «Україна має талант» режисер за пультом одночасно був режисером монтажу, який керував діями монтажера і за його допомогою зводив окремі записані фрагменти в єдине ціле, використовуючи «перебивні плани».

На менших проектах режисер, як правило, поєднує всі функції - режисерапостановника, режисера ПТС та режисера монтажу. Завдяки скоординованим діям цього фахівця глядач часто отримує саме те, що він хоче бачити на своєму екрані - майстерно підготовлений телевізійний проект.

В Європі монтаж проекту, як правило, здійснює інша особа. У західних країнах режисери забезпечені всім необхідним матеріалом і технікою для проведення зйомок.

У нашій країні при багатокамерному методі зйомок режисер розробляє проект зйомок, макет або план знімальних майданчиків, бере участь у роботі з освітленням майданчиків, розставлянні камер, безпосередньо керує знімальним процесом за допомогою пульта управління, здійснює монтаж готового проекту. Крім того, режисер перед початком зйомок прораховує кошторис проекту. Тобто режисер - це та людина, яка бездогано повинна розумітися на знімальній техніці та їі особливостях - як технічних, так і фінансових.

Хороший режисер телевізійної естради - це фахівець широкого профілю. Перед початком знімання видовища він повинен бачити його в композиційній цілісності, особливо, коли йдеться про пряму трансляцію. У процесі зйомок можуть бути 
непередбачувані цікаві кадри, яких міг не прорахувати режисер перед початком зйомок, але в цілому він повинен бачити «скелет» майбутнього заходу.

Для цього режисер замовляє детальний план-схему залу (площа залу розбивається на квадратні метри і масштабується), де буде проводитися зйомка видовища. На плані прописуються декорації, розташування камер та додаткової техніки, задіяної у процесі зйомок.

Режисер разом із операторською групою розробляє режисерський сценарій, включаючи в нього операторську експлікацію літературного матеріалу. Для уникнення помилок операторську експлікацію коректують кілька разів. Останнє операторське освоєння декорацій проводять безпосередньо перед зйомкою - аналог генеральної репетиції «для декорацій», коли коректується розташування знімальної, звукової і освітлювальної техніки.

3 компанією, яка займається декораціями, обговорюється чіткий план декорацій, які елементи, матеріали, атрибути будуть задіяні, прораховується бюджет. При цьому прораховується покрив підлоги (від найдешевшого пластикового покриття до найдорожчого - екранного), використання/не використання, і якщо так, то якого - екрана (світлодіодного, кластерного, плазменного), тип ілюмінації. Прораховуються функціональність і вартість іншого обладнання (сходи - пластикові чи зі світловими смужками, елементи нічного міста, стилізація фонтана, інші атрибути). Досить часто режисер опиняється перед вибором - взяти для декорацій справжні атрибути дійства, котре знімається, чи виконати стилізацію. Наприклад, на зйомках параду часто використовуються такі атрибути як гармата, воєнна машина, або телевізійна версія концерту «Ми - ехо», присвяченого Дню Перемоги [6]. Режисер з компанією, яка виконуватиме декорації, прораховує витривалість підлоги для такого обладнання, вартість транспортування тощо і тоді робить вибір - використати справжній атрибут чи його стилізацію.

Після розробки режисерського сценарію створюють розкадровку (макет, який складається зі схематичного зображення певної кількості майбутніх кадрів). Після здійснення розкадровки настає момент безпосередньої зйомки.

Перед початком зйомок дуже важливо знайти відповідну будівлю або відповідну під забудову точку в потрібному місці. Але не важливо, чи буде павільйон будуватися під певні завдання або це просто реконструкція старої будівлі (перепрофілювання), головний чинник, який слід тримати в голові, - це висота стелі, необхідна і достатня для павільйону.

Прикладом є проведення «Євробачення-2012» у спеціально збудованому для фестивалю Бакинському кристальному залі (Баку, Азербайджан), який вміщує 23 тис. глядачів, чи «Євробачення-2014» взагалі у промислових залах В\&W (Копенгаген, Данія), що вміщують 10 тис. глядачів.

Незалежно від того, чи є можливість вільного вибору місця розташування павільйону чи ні, повинні бути враховані ризики порушення звукоізоляції. Шосе, що знаходиться поблизу, залізниця, аеропорт, могутній радіопередавач можуть викликати серйозні інтерференційні проблеми.

Адже режисер, крім повної обізнаності в технологічних можливостях знімальної техніки, повинен прораховувати акустичні можливості приміщення, обладнаного для 
знімання. Повинен він також прораховувати необхідну освітлювальну техніку та можливості іії розміщення в павільйоні чи на майданчику.

При плануванні будівельно-монтажних робіт треба враховувати можливість майбутнього розширення. Хоча і бізнес-план під проектування, будівництво, оснащення і експлуатацію павільйонуповинен бути реальним, але слід передбачити, де в перспективі можливі розширення: чи будуть це додаткові площі павільйону або взагалі додатковий (новий) павільйон і т. д.

У проектуванні та побудові декорацій разом із режисером беруть участь художник освітлення (прораховує всі аспекти освітлення майбутнього заходу), художник декорацій (аналізує технічні можливості сценічного майданчика), художник костюмів.

Режисер у процесі зйомок співпрацює також з художником-постановником. Художник-постановник зі своєю групою займається образотворчо-декораційним рішенням видовища. Під його керівництвом здійснюється розробка і затвердження ескізів, а також контроль за їх виконанням і за раціональним використанням декоративних засобів. Під керівництвом художника-постановника працюють художник-декоратор, художник костюмів, художник-гример (проводиться спільна розробка костюма і гриму для кожного персонажа) і асистенти художників.

Група звукооператора також бере участь у створенні режисерського сценарію (здійснюють звукову експлікацію літературного тексту), складанні календарного плану і кошторису, керівництв. Звукорежисер персонально оцінює акустику сценічного або знімального павільйону і вплив на неї декорацій. Він відповідальний за підбір фонограм з фонотеки, синхронний запис і дубляж.

Кількість осіб, що входять до складу режисерської та знімальної груп, залежить від складності, обсягу та етапу підготовки видовища: мінімальна кількість учасників задіяна в підготовчий період, максимальна - при проведенні самого видовища.

Узагальнюючи, можливо умовно окреслити основний склад постановочної групи:

- режисерська група, що складається із режисера-постановника, режисера ПТС, асистента режисера;

- операторська група: оператор, оператор комбінованих зйомок, асистент оператора;

- звукооператор;

- художник-постановник, художник комбінованих зйомок, художник по костюмах, художник-декоратор, художник-гример, їх асистенти;

- автор літературного сценарію;

- композитор;

- монтажер.

Допоміжний склад включає всіх помічників (помічники режисера, оператора i т. д.), підсобних робочих, гримерів, фотографів, костюмерів, реквізиторів, техніків знімальної апаратури, освітлювачів, бригади постановників та інших працівників відділів і цехів, прикріплених до знімальної групи.

Такий склад режисерсько-постановочної групи зумовлює успішне виробництво видовища. Та найголовнішим критерієм має бути рівень освіченості організаторів, їхнє бажання зробити якісним «продукт» телеестради. Від цього залежить не тільки емоційна 
обстановка на виробничому майданчику, а й змістовне наповнення літературного сценарію майбутнього шоу.

\section{Лimepamypa:}

1. Багиров Э. Г. Очерки теории телевидения / Э. Г. Багиров. - Москва : Искусство, 2007. - 267 с. 2. Безклубенко С. Д. Телевизионное кино: Очерк теории / Сергей Данилович Безклубенко. - Київ : Искусство, 1975. - 280 с. 3. Вартанов А. С. Телевизионные зрелища / Анри Суренович Вартанов. - Москва, 1991. - 274 с. 4. Вильчек В. М. Под знаком ТВ / Всеволод Михайлович Вильчек. - Москва : Искусство, 1987. - 239 с. 5. Горюнова Н. Л. Художественно-выразительные средства экрана. Ч. 1. Пластическая выразительность кадра : учеб. пособ. / Н. Л. Горюнова. - Москва : ИПК РТР, 2000. - 41 с. б. Кониерт «Mь вечное эхо друг друга» [Электронный ресурс] / Светлана Рухля // Телеканал «Интер». Электронные данные. - 2015. - Режим доступа: http://inter.ua/ru/programs/entertaining/ concert_vechnoe_ekho 